\title{
Genetics Concept Mastery of High School Biology Teachers in Simeulue Archipelago Through Guided Teaching Strategy
}

\author{
Sariwulan Diana, \\ Department of Biology Education Faculty of Mathematics \\ and Science Education \\ Universitas Pendidikan Indonesia \\ Bandung, Indonesia \\ sariwulwul@yahoo.co.id
}

\author{
Arief Rachamatulloh \\ Department of Biology Education Faculty of Mathematics \\ and Science Education \\ Universitas Pendidikan Indonesia \\ Bandung, Indonesia
}

\begin{abstract}
The study aims is to show genetics conceptual mastery improvement of biology teacher in Simeulue archipelago as the result of the implementation guided teaching strategy. This study was a follow-up of the needs of high school biology teachers in Simeulue archipelago for deepening genetics concepts that is considered as the difficulties concept based on the findings of previous studies. The quasi experiment with pretest posttest design was used. The main instruments used in the form of questions about the genetics of the various levels of cognitive, which refers to the professional competence of teacher certification indicators and basic competencies of Curriculum 2013's for high school level. Biology teacher's mastery of genetic concept in Simeulue archipelago before the implementation of guided teaching strategy is very low which is at $30.7 \%$. After the implementation of guided teaching strategy, teacher's mastery of genetic concept is increased to $47.9 \%$, but it is still at low category with $\mathrm{N}$-gain 0.25 . Thus, the implementation of guided teaching strategy on teacher training has potency to increase mastery of genetic concept. Genetics concepts mastered by the teacher in the moderate category are the concepts of the mutation and protein synthesis, while structure of DNA, Mendel's laws and extending the law, heredity in humans, the function of DNA and cell division, were in low category. For future training, it is suggested that teachers learn in advance about the material that will be given, so when conceptual deepening were given teachers will be better prepared and motivated to develop.
\end{abstract}

Keywords-Biology teachers; genetics; Simeuleu archipelago

\section{INTRODUCTION}

Education as an investment for the future of the nation stressed on the implementation of good quality education, and thus qualified teachers are needed. Therefore, Indonesian Government Law No. 14 Year 2005 and Government Regulation No. 74 Year 2008 mandated that teachers are required to have academic qualifications, competence, teaching certificate, physically and mentally healthy, and have the ability to realize the goal of national education [1]. It was also stated that professional teachers are required to have academic qualifications that are relevant to the subject that they teach and also mastered the competencies as required by the law of teachers and lecturers.
According to the Jakarta Education Forum (JEF), for up to one year after Joko Widodo Cabinet, there has been no breakthrough in the field of education to address fundamental issues such as improving the quality of teachers [2]. Teacher quality is the most difficult challenge for the government which reflected by National Accreditation Board low accreditation results for School teachers in all levels of education [3].

Generally speaking, the competence of teachers in Indonesia who have passed the certification (professional teachers) at all levels of education and subjects, as stated in Law No. 14 Year 2005, is still relatively low, especially for pedagogic and professional competence [4]. Since 2006 the Directorate of Professional Educators PMPTK already carried out tests of professional competence to the teachers at all levels and all subject areas in the national scope, the results indicated that the professional competence of biology teachers is categorized in low category [5]

A condition that described the low competence of biology teacher, it is supported by the results of the initial competency test (ICT) for teachers who will carry out the certification in 2012. The results of the implementation of the ICT showed that the national average grade was under 50 in the range of 1$100[6 ; 7 ; 8]$, and it did not much changed from the results in 2015 which was in 53.02 [9]. Before implementing the ICT, testing the feasibility and competence of teachers, teachers' mastery of the subject in accordance with the subject that they taught is very low which is below $25 \%$ [10].

The test results of competence of teachers in Aceh province, including on Simeulue archipelago is in position 32 of the 34 provinces [11], which indicates that the professional competence of teachers, including biology teacher is the lowest compared to biology teacher in other province, even this result is lower than Papua and East Nusa Tenggara [12]. Similar to national results of special competence, biology teachers only reached in average of 52.87 [4]. This is showed that the condition of professional competence of biology teachers at Simeulue archipelago is very urgent and need to be improved. 
From a previous study, it was found that science teachers in West Java that participated Teacher Professional Education and Training, mastery of general concept in biology (PLPG) Rayon 110 only reached 51\% [13]. From this research, genetic concept can be mastered by the science teacher which is just 54\%. Board of Education and Human Resources Development Education Quality Assurance that analyzed ICT, stated that the absorption of about professional competence in the subject of Biology is still low [4]. One of the questions of professional competence for the biology teacher is about genetic concept. Genetic concept is also listed on essential indicators No. 08/01/16 to 8.1 .25 of the standard of competence lattice UKG Biology for High School in year of 2012 [14]. In UKG Biology for High School in 2014, it was also the genetic material contained in some essential indicators of Standard Competency number 3, namely to understand the application of the basic concepts and principles of heredity as well as its implications on science, environment, technology and society [15]. Thus, genetic concept is important and it is included some concept that difficult to be mastered by biology teacher. In fact, according to the survey conducted by [16] among the academic community in general, the knowledge of genetic concept was placed in the important level to be mastered by all citizens. In addition, from the results of a poll of biology teachers at high school, especially in the area of Simeulue archipelago in Aceh province, the genetic concept was one of the biological concept that is considered as the most difficult concept, so the provisioning of genetic concept becomes very important and in order to improve the quality of teachers, it is needed by teachers. This was also supported by the research from [17] and [18] found that genetic concept was one of biology lessons that perceived as difficult concept by both students and biology teachers and genetic concept was the concept that is the most needed in Biology teacher training [19]. According to [18] biology teachers are considered to see genetic concept is the difficult concept, due to its characteristics that are abstract and closely related to molecular biology.

Some related researches already available to improve the mastery of genetic concept at different levels of education, including through the implementation of teaching models directly to pre-service biology teachers [20], development of pedagogical content knowledge (PCK) to biology teachers [17], and development of lecturing system based on information and communication technology [18]. In addition to the increasing of mastery in the genetic concept, [21] suggested to the biology teacher to select biology textbooks according to the standard content of the concept before the books are given to students, applying the model of Problem Based Learning in the lecture [22], as well as learning by using concept maps and guided inquiry [23].

According to [24], although the biology teacher had been given training in biological concept, including genetic concept, but resulted unsatisfied. This indicates that the genetic concept cannot be solved with only training just for debriefing. Therefore, it is necessary for certain breakthrough business more structured, one of them through a training strategy guided teaching. According to [25], guided teaching is guided learning technique which is an outgrowth of lectures and allowing teachers to learn what is already known by students before making the points of learning, and it is ideal to use in the teaching of the concepts that are abstract.

Thus, the guided teaching strategy has the advantage, among others, which is teacher can reveal the level of mastery of the concept that is abstract perceived by students before start to learn, and teachers can immediately adjust the points of concept that will be submitted to the category of students are flexible. It is known that just a few of research on the implementation of the guided teaching strategy in learning, some studies showed a guided teaching technique could improve learning quality Advanced Solid State Physics [26] and also affects very well towards the understanding of jurisprudence students at MTs Tlasih Tulangan Sidoarjo [27]. It has not yet been done the research related to guided teaching strategy in order to improve biology teacher mastery of genetic concept, especially biology teachers in Simeulue archipelago.

\section{RESEARCH METHOD}

The method used in this study is quasi experiment with pretest and post test design, namely the achievement of biology teacher mastery of genetic concept before and after implementation of guided teaching strategies. This research was conducted under Department of Secondary Education Simeulue District Aceh province. The subject of research is 17 general high school and vocational high school biology teachers in Southwest Aceh District and Simeulue District in Aceh province following the Education and Training Teacher Competence in odd semester $\left(24^{\text {th }}\right.$ and $25^{\text {th }}$ November 2015). Guided teaching strategy applied in this study is an active learning strategies adapted from [25].

This study began with the planning phase which contains the formulation of the problems that faced and action plans. Furthermore, the problem is solved consisting of action, evaluation and follow-up action.

\section{A. Preparation}

Preparation for the implementation of this study was included: (1) Discussing the prior and important biological concept that perceived as difficult concept by biology teachers who attended Teacher Competency Training on Simeulue Aceh province; (2) studying the literature to find a variety of information related to this issues, including Curriculum 2013 for high school biology subject, the test of Biology teacher, journals and books related to the study; (3) the preparation of lesson plans in the training, including the preparation of guided teaching strategies and follow-up things; (4) preparation of genetic concept; (5) the preparation of learning tools, including research instruments such as issues concerning the genetic concept that mostly refers to indicators of professional competence certification of level of cognition and the indicators of basic competencies Curriculum 2013 high school level (Table 1). Materials that were provided contain the entire genetics topic and other concepts related to genetics in class XII. These issues have been tested prior to the high school Biology teachers throughout West Java province (analysis of test items) and have been revised. 


\section{B. Implementation and Evaluation}

Implementation in this study included: (1) the implementation of pre-test to reveal early biology teacher achievement in genetic concept that the results were used as the basis for the guided teaching implementation learning by [25] with some adjustments; (2) mentors introduced guided teaching strategy to teachers who attended the Teacher Training; (3) mentors delivered opening question in accordance with the subject of training; (4) teachers provided grading in the form of key concepts in genetics with learning materials; (5) teachers divided the teachers into three groups, each group was given the task of discussing the key concepts of genetic concept with a high degree of difficulty based on the results of the pretest, preparing media for learning to play role playing of synthesis protein and preparing media for learning peer teaching about irregularities in Mendel's laws, which then all tasks will be performed in the classroom; (6) the teachers together with the mentors concluded the concept that have been studied. After all stages of guided teaching were done, mentor provided evaluation through post-test.

In obtaining the pretest and posttest data, Biology teachers are conditioned to answer the questions about the genetics with 'closed book' way and to work independently for 90 minutes with the amount of about 30 multiple choice questions, 5 open ended questions, and 15 right wrong answers. All the answer sheets were checked and given a score of 10 for each question, so that the grade of the data obtained mastery of genetic concept to each teacher, the average grade of all the teachers that involved in this study, and the average grade of mastery the concept.

TABLE I. QUESTION MAPPING ACCORDING TO CONCEPTUAL DISTRIBUTION AND COGNITIVE LEVEL

\begin{tabular}{|l|l|l|}
\hline Question Number & \multicolumn{1}{|c|}{ Concepts } & Cognitive Level \\
\hline 1 & DNA Structure & Applying \\
\hline $3,44-48$ & DNA Structure & Remembering \\
\hline 38 & DNA Structure & Remembering \\
\hline 33 & DNA Function & Synthesing \\
\hline 2 & Synthesis of Protein & Applying \\
\hline 4,5 & Synthesis of Protein & Remembering \\
\hline 39 & Synthesis of Protein & Synthesing \\
\hline 31 & Synthesis of Protein & Analyzing \\
\hline 34 & Synthesis of Protein & Understanding \\
\hline 6,32 & Synthesis of Protein & Understanding \\
\hline $7,9-13,15-23$, & Mendel Law and its deviation & Analyzing \\
$25-29$ & & \\
\hline 8 & Mendel Law and its deviation & Applying \\
\hline 35 & Mendel Law and its deviation & Understanding \\
\hline $14,24,30$ & Human Heredity & Analyzing \\
\hline $41,49,50$ & Human Heredity & Remembering \\
\hline $36,37,40,43$ & Mutation & Remembering \\
\hline 42 & Biotechnology & Applying \\
\hline
\end{tabular}

To determine the increment in genetics concepts mastery, Normalized-gain ( $\mathrm{N}$-gain) was calculated and categorized according to Hake's equation [28] as follows.

$$
\mathrm{N}-\text { gain }=\frac{(\text { Posttest score }- \text { Pretest score })}{(\text { Maximum score }- \text { Pretest score })}
$$

\section{Follow-up}

Follow-up it that has been done in this research was reflecting on all phases of the actions and discussing from the biology teacher of about biological concept for further teacher training.

\section{RESULTS AND DISCUSSION}

Genetics concepts mastery according to its concepts distribution is presented in Table II.

\begin{tabular}{|c|c|c|c|c|}
\hline \multirow{2}{*}{ Concept } & \multicolumn{4}{|c|}{ Average Mastery (\%) } \\
\hline & Pretest & Posttest & N-Gain & Category \\
\hline DNA Structure & 28.7 & 39.0 & 0.14 & Low \\
\hline DNA Fuction & 5.9 & 31.2 & 0.27 & Low \\
\hline $\begin{array}{l}\text { Synthesis of } \\
\text { Protein }\end{array}$ & 31.2 & 61.9 & 0.45 & Moderate \\
\hline Cell Division & 21.6 & 42.8 & 0.27 & Low \\
\hline $\begin{array}{lr}\text { Mendel } & \text { Law } \\
\text { and } & \text { its } \\
\text { deviation } & \\
\end{array}$ & 26.6 & 39.6 & 0.18 & Low \\
\hline $\begin{array}{l}\text { Human } \\
\text { Heredity }\end{array}$ & 36.3 & 49.0 & 0.20 & Low \\
\hline Mutation & 52.9 & 79.4 & 0.56 & Moderate \\
\hline Biotechnology & 35.3 & 100.0 & 1.00 & High \\
\hline Total & 30.7 & 47.9 & 0.25 & Low \\
\hline
\end{tabular}

TABLE II. BIOLOGY TEACHER'S AVERAGE CONCEPTS MASTERY

Table II was proven that the biology teachers in Simeulue archipelago have a low mastery of genetic concepts, which is supported by poll results in the previous teacher training, which was only $30.7 \%$ in average. Difficulty in mastering the genetic concept is proved not only felt by the biology teacher in Simeulue, but also felt by students and teachers of biology in general $[13 ; 17 ; 18 ; 19 ; 23]$. The concept that mastered in the lowest level by all of the teachers was function of DNA (Table II). When do the implementation phase of the action as part of a guided teaching strategy, especially when the mentor gave the assignment to the teachers, the classroom atmosphere becomes very stiff, as if the teacher choked and very familiar with the concepts assigned. Moreover, it will be presented. Thus, the mentor gave a briefing first by re-introducing the related concepts, especially on molecular genetics, slowly, gradually and repeatedly, until the teachers could understand. As happened to pre-service biology teachers at the University of Nusantara PGRI Kediri, they generally still have misconceptions about the genetic structure and regulation of gene expression [29]. In addition, according to [30] that the misconceptions most experienced teachers are at KD 6.2 on the concept of heredity in a living organism. Even, [20] stated that to improve learning outcomes in genetics can be done through direct teaching that have been done to pre-service biology teachers in FKIP of Riau.

After training with the ways of implementing guided teaching strategy that focused on discussion and discussion of key concepts of genetic concepts with high degree of difficulty based on the results of pretest (i.e the material essentially contained in the concept and not discuss the question directly), then it was followed with role playing and peer teaching, increasing mastery of concept is still relatively low, with an average posttest $47.9 \%$ and the value of $\mathrm{N}$-gain average of 0.25 . This result is similar to [321] which showed slow improvement in genetic literacy of non science students as a result of genetics lectures with $\mathrm{N}$-gain values ranging from 
0.01 to 0.25 . This suggests that the genetic concept is not easily controlled, even though it has been taught with the implementation of guided teaching strategy. This similar to what [4] stated that activities to improve the competency of teachers (professional competence) must be based on sustainable, and the possibility of genetic concept on the mastery should be monitored again in the future teachers training. It is also stated by [24] that even the biology teacher had been given training in biological concept, including genetic concept, but that results were still limited, and indicated that genetic concept cannot be solved only with the debriefing training method.

Despite the increasing mastery of genetic concept by the biology teachers in Simeulue archipelago is still relatively low, but an outline of the implementation of the training to implement guided teaching strategy could be said has the potential to develop the competence of teachers. As well as the application of guided teaching techniques by [26], which are proven to improve the quality of teaching Advanced Solid State Physics and also had better influence on the understanding of the jurisprudence of students at MTs Tlasih Tulangan Sidoarjo [27].

Nonetheless, from concept distribution of those genetics material, it appears that mastery increment varies from high, medium and low. Mastery for Biotechnology concepts ranked as the highest increment. All the teachers were able to give examples of transgenic animals. The second genetic material which mastered quite well by biology teachers was mutations (posttest score average 79.4\%) and followed with the concept of protein synthesis (average post-test score 61.9\%). The concepts of mutation netted through questions that contain levels of cognition 'remembering'. It was thus no surprise that the biology teacher can soon master it. In contrast to the concept of mutation, the concept of protein synthesis were netted in varying levels of cognitive level, starting from 'remembering', 'understanding', 'applying', 'analyzing' and 'synthesizing'. Almost all teachers (88\%) can answer the question No. 4 on the posttest, which were question about transcription. This was in accordance with the theory that the result of transcription is mRNA [32;33]. But when the concept of transcription and translation were asked again in the other question (essay question), only $76 \%$ of teachers can answer it correctly. Actually, all teachers should be able to synthesize characteristics of transcription and translation in the form of a chart, because before posttest was conducted they already organized and conducted 'role play' peer teaching about protein synthesis material including making and using media.

Although the covered material were already addressed and discussed, applied in peer teaching and learning methods, and the media about the synthesis of proteins has also been created, but mastery about structure of DNA as the basic concept were still low. This shows that the teachers not fully mastered yet the basic theory of genetics, thus training of genetic material specifically DNA structures still need to be developed and strengthened.

Mendel's laws and its deviation, such as genes interaction, cryptomery, epistasis - hypostasis, polymery and so forth, also fall in low mastery category. In the training, in addition to the discussion of essential materials, teachers were also trained to make learning media to implement and prove the apparent irregularities of Mendel's laws, and even peer teaching was also conducted. This shows that although most of the Biology teachers in Simeulue archipelago disciplinary background is biology, but it has not been used to perform analysis and it even seem as though they were completely new to the concept of Mendel's laws and its deviations. Probably, biology teacher in the Simeulue archipelago should have learned about genetics material before training, because if mastery of the concept is very weak and then they were suddenly given training by answering the question and then followed by the discussion about essential materials, the result is not optimal and it seems that teachers felt "a burden" to accept it. Some teachers do not have educational background in biology and become a teacher in their village voluntarily. In addition, most teachers despite having background in biology, argued that they do not teach in class XII so they feel "foreign" to the genetic material.

Competency of Biology teachers in the Simeulue archipelago was not commensurate with the findings of [34] that the performance of pedagogical competence of teachers who have been certified in high school Rayon 01 Pidie Aceh District ranged from adequate, good and excellent, while the teachers who have not been certified yet in medium, low and high categories.

Things like this could have been an iceberg phenomenon for teachers' quality in various corners of the country that should be addressed together with the local community as MGMPs and teachers can empower potential internal and external supervisors, especially those related to academic supervision. According to [35] professional education personnel that serve as the executive element of the academic supervision is a school superintendent. According to [36] principals are not ready to take a tough task as a manager-level in schools education, including teacher management. According to [8] many principals were not able to assess in a professional manner and give pedagogy advice to teachers. According to [4] in the implementation of the necessary activities are always strengthening the aspects of monitoring by the employer (school subjects supervisor or principal) is done periodically every academic activities and professional development.. Thereby improving the quality of education, especially the quality of teachers is necessarily worked together with all of educational stakeholder.

\section{CONCLUSION}

Biology teachers' mastery of genetic concepts in Simeulue archipelago prior to the training was very low. After the training that was done through the implementation of guided teaching strategies mastery of genetic concept of biology teachers are increased, although still in a low level. Thus, teacher training through the implementation of guided teaching strategy that includes a discussion of essential concept, implementing learning through role playing and peer teaching, has the potential in improving biology teacher's mastery on genetic concept. Therefore, this strategy can be further developed by way giving the assignment to teachers in 
order to learn in advance the concept that will be taught, so when given the training of the teachers have better prepared cognitively and motivated to develop.

Genetic concept which has been mastered by the teacher in the moderate category were mutation and protein synthesis, other mastered genetic concept that still in low category were structure of DNA, Mendel's laws and its deviation, heredity in humans, the function of DNA and cell division. Biology teachers should be more developed in the ability of synthesizing and analizing genetic concepts.

\section{References}

[1] Direktur Jenderal Pendidikan Tinggi Kementrian Pendidikan dan Kebudayaan, Rambu-Rambu Pelaksanaan Pendidikan dan Latihan Profesi Guru (PLPG), 2012.

[2] Kompas, "Pendidikan Minus Terobosan," November $27^{\text {th }} 2015$, pp. 11.

[3] J. Damanik, "Akses Kependidikan: Kualitas Guru Menjadi Tantangan Terberat," in Kompas, January $2^{\text {nd }} 2016$, pp. 12.

[4] S. Anif, "Pengembangan Model Peningkatan Kompetensi Profesional Guru Biologi Berbasis Continuous Professional Development (CPD) di Surakarta," in University Research Colloquium, 2015, pp. 271 - 283.

[5] DirektoratTenagaKependidikan, Ditjen MPMTK Depdiknas, "Laporan Uji Kompetensi Guru Nasional Tahun 2006", Jakarta: Proyek BERMUTU, Peningkatan Kompetensi Guru 2007.

[6] E.L. Napitupulu, "Guru Butuh Jawaban,” in Kompas, May $1^{\text {st }} 2012$, pp.6.

[7] Sarwanto, "Refleksi Uji Kompetensi Guru IPA Tahun 2012”, pp. 395 401. Retrieved from http://jurnal.fkip.uns.ac.id/index.php/prosfis1/article/download/3767/265 $\underline{0}$

[8] L. Aulia, "Tidak Ada Kompromi untuk Kualitas Guru," in Kompas, December $17^{\text {th }} 2015$, pp. 6 .

[9] Kompas, "Tenaga Kependidikan: Pengetahuan Guru tentang Pembelajaran Masih Rendah", December 31 ${ }^{\text {th }} 2015$, pp. 9.

[10] Kompas, "873.650 Guru Tak Cocok: Tempatkan Guru Sesuai Kebutuhan," July $19^{\text {th }} 2011$, pp.6.

[11] S. Mahdi, "Dosa Birokrasi terhadap Pendidikan," in Kompas, February $3^{\text {th }} 2016$, pp. 7.

[12] R. Iskandar, "Hasil Uji Kompetensi Guru Provinsi Aceh Memprihatinkan," in Lintas Gayo, August $9^{\text {th }} 2012$.

[13] S. Diana, "Penguasaan Awal Materi Biologi Guru IPA Peserta PLPG menurut Taksonomi Baru Marzano," in Prosiding Seminar Nasional Pendidikan dan Penelitian Biologi 2013, Bandung: FPMIPA Universitas Pendidikan Indonesia, June 2013, pp. 183-189.

[14] Kisi-Kisi Uji Kompetensi Guru Biologi SMA, 2012, Retrieved from https://gurutikjateng.files.wordpress.com/2012/07/biologi_sma.pdf

[15] Kisi-Kisi Uji Kompetensi 2014 Mata Pelajaran Biologi, 2014, Retrieved from https://kangtofa.files.wordpress.com/2015/09/kisi-kisi-soal-ukgbiologi-sma.pdf

[16] J.R. Howell, M.F. McDonald, P. Esplin, G. B. Schaalje, and G.M. Booth, "What Biology Concepts are Important in General Education?: A Survey of Faculty Members and Students," in Science Education and Civic Engagement, vol. 4(1), 2012, pp. 38-46.

[17] D. Hamidah, Pengembangan Profesoinal Guru Biologi SMA melalui Program Pelatihan Pedagogical Content Knowledge pada Materi Genetika, in UPI repository.upi.edu., 2013.

[18] Riandi, "Pengembangan Sistem Perkuliahan Genetika Berbasis teknologi Informasi dan Komunikasi (GeneTIK) untuk Meningkatkan Kebermaknaan Belajar dan keterampilan Berpikir Kritis Mahasiswa Calon Guru Biologi,"Ringkasan Disertasi SPs UPI, 2010, unpublished.

[19] A. Widodo, Riandi, and N. Hana, "Dual Mode Inservice Training As An Alternative Teachers Professional Development Program," in
Proceeding The Second International Seminar an Science Education, Bandung: Science Education program, Graduate School Indonesia University of Education, October $18^{\text {th }} 2008$, pp. 150-154.

[20] Darmawati, "Peningkatan Hasil Belajar Genetika Melalui Model Pengajaran Langsung (Direct Instruction) pada Mahasiswa Biologi FKIP UNRI," in Jurnal Pendidikan 2009, pp. 30.1- 30.5. Retrieved from http://ejournal.unri.ac.id/index.php/JP/article/download/648/641

[21] E. Nusantari, "Jenis Miskonsepsi Genetika yang Ditemukan pada Buku Ajar di Sekolah Menengah Atas," in Jurnal Pendidikan Sains, vol. 1(1), 2013, pp. 52-64.

[22] Darmawati, "Peningkatan Kemampuan Generik Mahasiswa Biologi FKIP UR pada Matakuliah Genetika dan Evolusi Melalui Penerapan Model Problem Based Learning (PBL)," Jurnal Biogenesis, vol. 11(2), 2015,pp. 159-168.

[23] C. Roini, A.D. Corebima, S.B. Sumitro, and S. Zubaidah, "Kajian Miskonsepsi Genetika dan Upaya Mengatasinya dengan Pembelajaran Peta Konsep dan Inkuiri Terbimbing Menggunakan Perangkat Berpendekatan Konsep pada SMA Berkategori Berbeda," Disertasi Program Pascasarjana UM, 2013, unpublished.

[24] Meilinda, N. Rustaman, and A. Widodo, "Efektifitas E-Modul Interaktif Berbasis Konstruktivisme pada Materi Genetika untuk Meningkatkan Kompetensi Guru Biologi SLTP," Jurnal Penelitian Pendidikan IPA, vol. 3(2), 2009, pp. 153-163.

[25] M. Silberman, Active Learning: 101 Strategi Pembelajaran Aktif, Sarjuli et al. (Translaters), B. Munthe et al. Eds. Yogyakarta: Pustaka Insan Madani 2002, pp. 116-117.

[26] E. Istiyono, R.Y.A. Sari, Ariswan, H. Kuswanto, and Suparno. "Lesson Study Dengan Teknik Guided Teaching Sebagai Upaya untuk Meningkatkan Kualitas Pembelajaran Fisika Zat Padat Lanjut," in Prosiding Seminar Nasional Penelitian, Pendidikan, dan Penerapan MIPA, Yogyakarta: Fakultas MIPA, UNY, May 2009, pp. PF-217-PF223.

[27] S. Safridah, Pengaruh Penggunaan Strategi Guided Teaching Terhadap Pemahaman Siswa Pada Bidang Studi Fiqih di MTs Negeri Tlasih Tulangan Sidoarjo, Skipsi Program Studi Pendidikan Agama Islam Fakultas Tarbiyah UIN Surabaya, 2016.

[28] R.R. Hake, "The Impact of Concept Inventories On Physics Education and It's Relevance For Engineering Education" in http://www.physics.indiana.edu/ hake. January $\underline{18}^{\text {th }} 2013$.

[29] P.R. Primandiri and A.M. Santoso, "Evaluasi Perkuliahan Genetika untuk Calon Guru Biologi di Universitas Nusantara PGRI Kediri,” in Prosiding Seminar Nasional XII Pendidikan Biologi, Solo: Program Studi FKIP UNS, November 2015, pp. 183-189.

[30] Meilinda and M.M. Tabrani, "Identification of Biology Science Teacher's Misconception on Junior High School in Palembang,"in Proceeding $5^{\text {th }}$ International Seminar on Science Education, Bandung: SPs UPI, October 2011,pp. 2.1-2.9

[31] B.V. Bowling, C.A. Huether, L. Wang, M.F. Myers, G.C. Markle, G.E. Dean, EE. Acra, F.P. Wray, and G.A. Jacob, "Genetic Literacy of Undergraduate Non-Science Majors and the Impact of Introductory Biology and Genetics Courses," BioScience, vol. 58(7), 2008, pp. $654-$ 660.

[32] S. Prentis, Biotechology, Jakarta: Erlangga, 1990.

[33] J.W. Kimball, Biology $5^{\text {th }}$ ed., Jakarta: Erlangga, 1987.

[34] M. Nasir, Samingan, and Abdullah, "Studi Komparatif Kinerja Guru Biologi yang Belum Sertifikasi dengan Guru Biologi yang sudah Sertifikasi pada SMA Negeri Rayon 01 Kabupaten Pidie,” Jurnal Biologi Edukasi, vol.5 (2), 2013, pp. 60-65.

[35] Direktur Jenderal Peningkatan Mutu Pendidikdan Tenaga Kependidikan Departemen Pendidikan Nasional, Penyusunan Program Pengawasan Sekolah, 2008.

[36] Paramadina Public Policy Institute, "Manajemen Kependidikan: Kepala Sekolah Tak Siap Emban Tugas Berat," in Kompas, Januari $7^{\text {th }} 2016$, pp. 